\title{
Fe-2Mn-0.36C 合金の焼もどしマルテンサイトにおけるセメンタイトの高分解能電頙観察
}

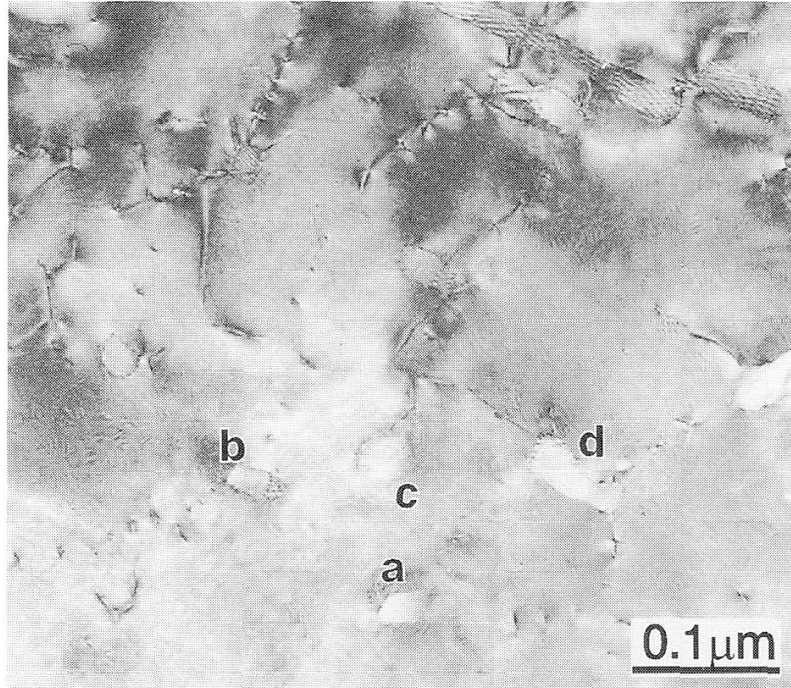

Fig. $1 \mathrm{Fe}-2 \mathrm{Mn}-0.36 \mathrm{C}$ 合金に抢けるセメンタイトの大 きさと分布を示す低倍写真. 図中記号について は本文参照。

高強度鋼焼もどしマルテンサイトは，母相フェライ ト中に微細なセメンタイトが多数分散している組織を 持つ。この組織は実用的に重要であるにもかかわら ず，フェライトーセメンタイトの結晶方位関係や，そ の界面構造などの基本的な結晶学については不明な点 が多い，結晶方位関係については，Bagaryatskii の方 位関係で嵓るとする報告(1)や，Isaichev の方位関係で あるとするもの(2)がある。また，析出サイトによっ てその両方が存在するといら報告(3) 孔なされている.

これら二つの方位関係は互いにわずかな差しかない ため制限視野電子回折では区別がしにくく，杰た，七 メンタイトが微小なために精密な方位解析に必要な十 分な強度の菊池線が得られないといら問題がある。本 研究では中炭素鋼の焼もどしマルテンサイト組織に拝 けるフェライトーセメンタイトの結晶方位関係と界面 構造を決定することを目的として，上記の二つの結晶 方位関係を考慮したうえで特定の方向からの高分解能 電顕観察を行った。

供試材には Fe-2Mn-0.36C(mass\%)委用い，熱処 理として $1373 \mathrm{~K} 60 \mathrm{~s} \rightarrow$ W.Q.+923 K $15 \mathrm{~s} \rightarrow$ W.Q. を 施した。 TEM 試料は電解研磨法(酢酸一過塩素酸混液 を用いてッインジェット法で穴を開けた後に燐酸ーク ロム酸溶液で仕上げ研磨)で作製した。

Fig. 1 はセメンタイトの大きさと分布を示寸低倍 写真である。セメンタイトの大きさは平均で $70 \mathrm{~nm}$
金属材料技術研究所原徹津㠃兼彰
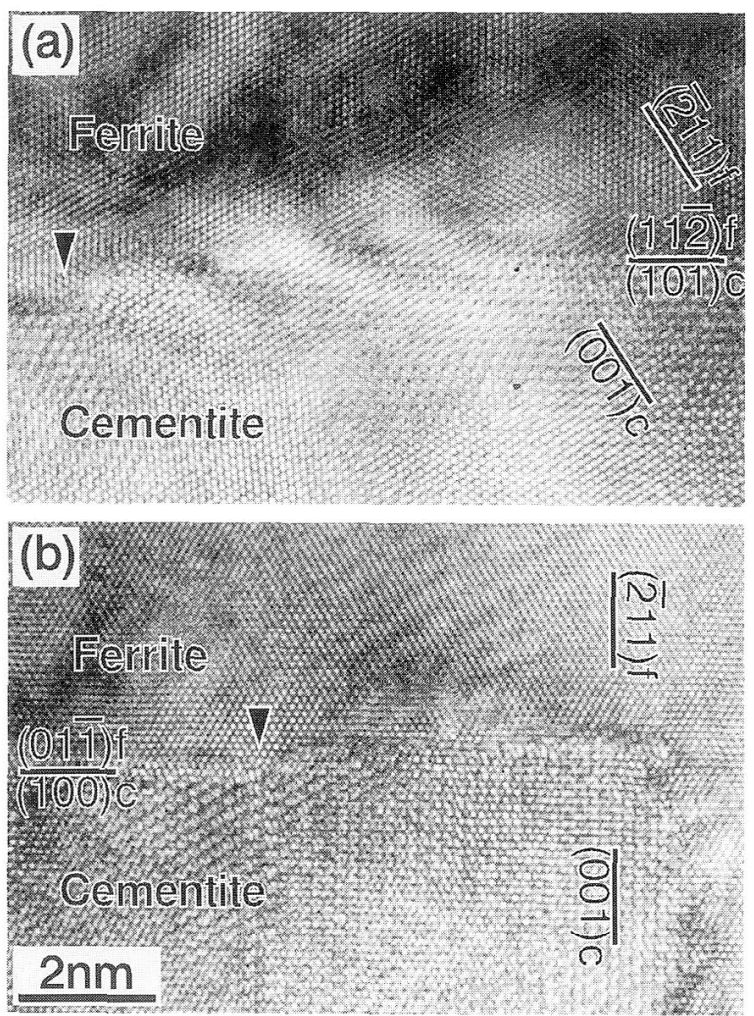

Fig. 2 フェライトーセメンタイト界面の格子像. 入射 電子線の方位は[111]f//[010]c . (a) は Isaichevの結晶方位関係飞従5。(b) 任 Bagaryatskii の結晶方位関係従う。

程度でめった。

Fig.2(a) はIsaichev の方位関係慈らフェライ トーセメンタイト界面の格子像で, 晶癖面は $(11 \overline{2}) \mathrm{f} / /$ (101)cである.（b) は Bagaryatskii の方位関係に従 らわので, 晶癖面は (011) f f// (100)c である. Fig. 1 で は と c は Isaichev, b とd は Bagaryatskii の方位関

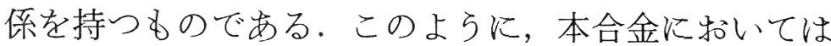
二種類の方位関係が混在していることがわかった。ま た，どちらの方位関係促う場合でもセメンタイト中 には (001)c 面上にすべりのトレースが観察され(図中 矢印)，それ伴って界面にステップが形成されてい る。

\section{文献}

(1) M. G. H. Wells: Acta Metall., 12(1964), 389.

(2) M.-X. Zhang and P. M. Kelly: Acta Mater., 46(1998), 4081.

( 3 ) Y. Ohmori, A. T. Davenport and R. W. K. Honeycombe: Trans. ISIJ, 12 (1972), 112.

(2000年 8 月11日受理)

High Resolution Electron Microscopy of Cementite in Fe-2Mn-0.36C Tempered Martensite; Toru Hara, Kaneaki Tsuzaki(National

Research Institute for Metals, Tsukuba, Ibaraki)

Keywords: tempered martensitic steel, cementite, orientation relationships, interface structure

TEM specimen preparation: electropolishing TEM utilized: JEOL JEM-2010F with I.P. 